\title{
Bridging the Gap between Producers and Consumers of Himachali Fruit Wines
}

\author{
Suresh Chauhan, ${ }^{*}$ Sukarn Sharma ${ }^{\dagger}$ and Yenesew Alene ${ }^{\ddagger}$
}

\section{Abstract}

Tourism is travel for recreational, leisure or business purposes. This vast industry is associated with different services like Accommodation, Food and Beverage services, Travel services, Recreation and Entertainment. These days tourists not only look for vacations and travel-they seek cultural education, historical significance, natural or inbuilt beauty, and to taste local cuisine and beverages. In Beverages especially, wines play an important role. Winemaking has existed throughout Indian history but was particularly encouraged by Portugal and the United Kingdom. The Old Testament in the Bible gives evidence of existence of wines, but there is a definite evidence of its use in China in 2000 BC and in Egypt in 3000 BC. Having a well established name in fruit juices, Himachal Pradesh (a northern hill state in India) has planned to venture in the area of fruit wines. To know the present position of Himachal's wine industry and the gaps therein, a research was conducted. It was found that Himachal's wine industry should address issues like availability of multiple flavours of fruit wines and stiff competition with

\footnotetext{
The Pavement (Indian and Chinese Restaurant), Kisementi; sureshshyama2003@gmail.com

† Department of Tourism Management, University of Gondar, Ethiopia; sukarnsharma@gmail.com

‡ Department of Tourism Management, University of Gondar, Ethiopia; yene.alene@gmail.com
} 
beer and breezer. However, the industry can take advantage of three factors associated with these wines viz. health, flavour, and price. This can help Himachal to set up the same benchmark as it has done in case of juices.

Keywords: Culinary tourism, Beverage, Winemaking, Fruit wines, Alcohol, Hospitality, Viticulture, Cider

\section{Introduction}

Tourism is a dynamic and competitive industry divided into different sectors, namely, Accommodation, Recreation and Entertainment, Transportation, Travel Services and Food \& Beverage Services ( go2, 2012). Wine is an important segment in food and beverage service and has a very rich history. The Old Testament in the Bible gives evidence of the existence of wines, but there is a definite evidence of its use in China in 2000 BC and in Egypt in 3000 BC.(Andrews, 2009).

Wine is an alcoholic beverage obtained from the fermentation of the juice of freshly gathered grapes (Lillicrap, Cousins, \& Smith 1998). Many wine regions around the world have found it financially beneficial to promote tourism. Growers' associations and others in the hospitality industry in wine regions have spent significant amounts of money over the years to promote such tourism (wine tourism, 2009).

\section{Food and Beverage Sector}

Food and Beverage Services is an integral part of tourism, accounting for nearly 50 per cent of the total tourism workforce. Culinary tourism is becoming a rage these days. People want to do more than take vacations and travel - they seek cultural education too, and this is provided in part by the experience of tasting a local cuisine (KNG, 2011). Most of the beverages supply energy in the form of sugar or alcohol which can be broadly classified into two categories, namely, non-alcoholic such as Aerated, spring water/mineral water, squash, juices, syrups, tea, and coffee, cocoa and alcoholic such as whiskey, brandy, rum, vodka, gin, beer and wine (Classification of beverages, 2011) 
Viticulture in India has a long history dating back to the time of the Indus valley civilization when grapevines were believed to have been introduced from Persia (Indian wine, 2011). Barr H (2012) has cited Wade (1999) thus: "The effects of alcohol were probably discovered when rotten fruit was consumed and found to have an intoxicating effect, which was viewed as pleasant. Fermented liquid could be stored for a long time without fear of decomposition, and a reliable drinking source was obtained. Yeast is added to a solution containing glucose, and the yeast cells convert the simple sugars to ethanol and carbon dioxide. The alcoholic solution that results from fermentation contains about 12$15 \%$ ethanol, as yeast cells cannot survive in higher concentrations of ethanol."

Fruit wines play a major role in Indian wines; these are fermented alcoholic beverages made from a variety of base ingredients (other than Grape). They may have additional flavors taken from fruit flower and herb. Fruit wines are usually referred by their main ingredient (fruit wines, 2011).

"Consumption of imported wines, essentially concentrated in the country's major cities, doubled between 2004 and 2008". Fruit wines have also been available in Himachal Pradesh for a number of years, where local rules allow for easy licensing, and any retailer can sell the locally-produced wines with low one-time duty and no further involvement of the state excise machinery (Indian wine, 2011). Indian cider is mainly produced in the Himachal Pradesh in Northern India. Cider made from apple, peer, plum, peach and other fruits is produced and marketed by state run firms such as HPMC (HP Horticulture Produce Marketing and Processing Corporation Ltd.) and private firms such as Minchys (under the brand name Wonderwyne and Green Valley (Tempest Cider). Cider is a fermented alcoholic beverage made from fruit juice, most commonly and traditionally apple juice, but also the juice of peaches or other fruits. Cider varies in alcoholic content from $2 \%$ ABV TO 8.5\% or more (Cider, 2011).

HPMC which markets wines under its own brand sells around 70,000 $750 \mathrm{ml}$ bottles, priced around Rs 150 through its 21 retailers in the local market every year. Sales are projected to grow at $15-20$ 
percent by the end of the year with the introduction of cheaper tetra packed varieties (Indian Express, 2006).

\section{Review of Literature}

According to Oliver (1993), satisfaction links purchase/consumption to post-purchase phenomena such as repeat purchase, positive word-of mouth, and brand loyalty. Satisfaction occurs when actual performance is greater than or equal to expected performance (Oliver, 1996; Yuksel \& Rimmington, 1998). In addition, customer satisfaction can be explained as a post consumption evaluative judgment concerning a product or a service (Yuksel \& Rimmington, 1998).

O'Neil and Charters, (2000) have found that increased significance and growing competitiveness of wine tourism has led to a heightened concern by producers and consumers for the quality of services being offered, and has forced many within the industry to invest in the delivery of higher levels of service quality as a means to achieving competitive differentiation. An integral part of any organisation's attempt to deliver on this front is a commitment to the process of continuous quality improvement. This requires a systematic approach to quality measurement.

Hsu, Kang and Wolfe (2002) have stated that one approach to examine satisfaction and future intention to purchase wines and to segment advertising can be according to demographic and psychographic qualities.

Caroline Keown and Mura Casey, (1995) have identified that a dynamic process of structural change is currently under way in the global wine industry. Historically, the wine industry has been dominated by the traditional wine-producing countries of Europe. However, forces of change in the commercial environment have encouraged an influx of wines from countries such as California, Chile, Australia and New Zealand, to name but a few. As the portfolio of wines on the market continues to expand, the challenge for survival of both new and traditional wine-producing countries is intensified. The key findings in their study in Northern Ireland wine market include that country of origin is the most important factor when customers are selecting wine; word of mouth 
recommendation is most likely to influence the type of wine chosen; most of those surveyed usually spend between $£ 3.50$ and $£ 4.49$ on a bottle of wine.

\section{Statement of Problem}

Himachal Pradesh registered a record growth in tourist arrivals in 2010 i.e.1.32 crore (Zeenews.com, 2011) which is double the state population. Himachali fruit juices are also quite famous with the tourists, not only from every nook and corner of India but also from abroad. Himachal is also illustrious for apple and apricot orchards. The total area under fruit in Himachal Pradesh is about 2.07 Lac hectares with a production of about 5.00 Lac MTs of all kinds of fruits. Apple is the major fruit accounting for more than $40 \%$ of total area under fruits and about $88 \%$ of total fruit production. The state is successfully growing fruits such as apple, pear, peach plum, almond, walnut, citrus, mango, raisin grapes etc. Commercially, apple is the most important of all the fresh fruits grown. It has a rich collection of as many as 450 cultivars of apples collected from all over the World. Himachal Pradesh currently accounts for over 4 lakh tonnes of apple production annually. It has been recognized as the Apple State of India and is regarded as the best producer of Quality Apples.

Himachal has also entered into the foray of fruit wines. However, for the expansion and growth of Himachal's wine industry there is a need to understand the needs of the customers and the gaps therein. To understand this there arise a few questions that need to be answered, such as: which is the most popular fruit wine? Has the state been able to maintain its position in wines as it has been able to do in case of juices? Is there a need gap between the consumer and the producer of Himachali fruit wines?

\section{Research Design}

Keeping the above problems in view, it was decided to collect the feedback of the wine drinkers. Therefore, an interview schedule was prepared after discussion with a panel of experts from the wine industry. The data used in the current study was collected from the wine shops located in four important towns of Himachal 
Pradesh i.e. Solan, Shimla, Mandi and Hamirpur to have a holistic view. The number of customers who visited the selected wine shops in cities mentioned above were 120, 75, 110 and 90 respectively for three days in which the study was conducted. The sample was chosen, based on convenience sampling technique. A pilot test was performed by interviewing ten respondents at Solan wine shop. A total of 102 customers (wine drinkers) were interviewed.

\section{Findings}

It was found from the respondent profile that mostly married $(74.50 \%)$ male $(93.13 \%)$ of age group between $19-25$ (63.75\%) with a family size of four members (38.23\%) and $(25.49 \%)$ of five members have tried Himachali fruit wine. People who have minimum secondary level qualification (39.21\%), undergraduate $(33.33 \%)$ and are students (also verified from age group) (42.15\%) prefer Himachali fruit wine. As far as the income part is concerned, it was found that people from all the income strata love to enjoy Himachali fruit wines (less than $10000=30.39 \%$, between 10000 and $20000=34.31 \%$, greater than $20000=35.29 \%$ ). $80.39 \%$ of the respondents have tried single flavor fruit wines. Among all fruit wines it has been found that apple wine $(83.13 \%)$ is the most popular fruit wine. The respondents have suggested that the fruit wines should also be available in these flavors (mango $(23.33 \%$ ), Strawberry $(10 \%)$, Berry $(10 \%)$, Banana $(10 \%)$, and Gooseberry $(6.66 \%))$. There are some other flavors also but there are only few respondents who have stated that wines of them should be prepared. $62.74 \%$ of people believe that Himachali fruit wine has positive effect on their health. Sequence of flavor, health and price is rated by $29.41 \%$ respondents followed by the sequence of price, health and flavor (21.56\%). $48.03 \%$ respondents have rated fruit wines as an all season drink and $22.54 \%$ of the respondents have stated that it is a drink for summer. Surprisingly even though it is enjoyed during all the seasons, Himachali wine is still considered as an occasional drink (58.82\%). Respondents treat Himachali fruit wines in the category of other alcoholic drinks which are usually consumed before meal $(49.01 \%)$ or with meal $(28.43 \%)$. In terms of quality $30.0 \%$ of the respondents have stated that Himachali fruit 
wines are better than other fruit wines while $46.0 \%$ of the respondents feel it at par.

$38.22 \%$ of the respondents feel that the flavor of Himachali fruit wines is good. However the remaining respondents have not stated anything in favor or against the flavor of Himachali fruit wine. $74.50 \%$ of the respondents are quite happy with its availability within the State and feel that the packaging and the color is also satisfactory. A small percentage of respondents also consider that Himachali fruit wines helps in digestion and a few respondents believe that it is a party wine. $32.35 \%$ of the respondents have rated beer and $27.45 \%$ of the respondents have rated Breezer as the stiffest competitors of Himachali fruit wines followed by other wines and vodka.

The study also revealed that among food and snacks, vegetarian snacks are considered to be the best combination for Himachali fruit wine. $50 \%$ of people prefer vegetarian snacks and $28.43 \%$ prefer non vegetarian snacks with Himachali fruit wine.

Majority of people (48.14\%) have come to know about Himachali fruit wines from wine shops followed by word of mouth $(29.41 \%)$. A very small bunch of respondents feel that the packaging, low alcoholic percentage, non availability outside Himachal Pradesh, high cost factor, smell, taste, fragrance, marketing and hangover are some small niggling issues which should be taken care of by the wine producers.

\section{Conclusion}

After being famous for its juices Himachal Pradesh has entered into the market of fruit wines. To know whether Himachal has got the same place for itself as in juices, a research was conducted. Therefore, a schedule was prepared and the customers (wine drinkers) were interviewed to understand the negative and positive aspects of this industry.

It was found that target market for Himachali fruit wines are married males in the age group of 19-25 with a family size of four members. Therefore the producers should see the tastes of this market group and devise its marketing policies accordingly. No 
distinction was noticed as far as the educational and income level of the segment is concerned and for this reason these factors will not be very helpful in devising a strategy. As expected apple fruit wine has topped the list and therefore, this wine can act as the flagship wine of Himachal Pradesh. It was also noticed that people are quite interested in having more single flavors of Himachali fruit wines especially of Mango; so this is an upcoming market for the producers and they should put in maximum efforts to tap this market segment as well. Health has been considered as an important factor for drinking Himachali fruit wines (However, by no means has this research suggested taking large quantities of fruit wine. According to literature review fruit wines are only good if taken in moderate quantity). Therefore, the producers while promoting their wines should also educate the people about this fact. An organisation should never forget its role of corporate social responsibility.

Flavour and price of the wines have also been rated positively. Therefore, these factors can help in a year around promotion of the same especially when these wines are also considered an all season drink. The producers should try to draw differentiation of Himachali fruit wines from other alcoholic drinks by promoting the health, flavor and price factors so that they can carve out a niche for themselves. The competition to Himachali fruit wines is posed by beer, breezers and wines from other places. Therefore, a close watch should be kept on the activities of these competitors. It is interesting to mention that vegetarian snacks are preferred with Himachali fruit wines; therefore, these should be brought to the notice of the producers of these snacks (readymade or at restaurants) so that they can prepare some combos and in return can help in increasing sales. The display of wines at wine shops has been quite good and therefore, the producers should keep encouraging the retailers by giving some sort of incentives so that their wines are displayed properly.

\section{References}

Andrews, S. (2009) Food and Beverage Service Training Manual (2nd edition), New Delhi, Tata McGraw-Hill 
Cider. (2011). Retrieved from Web site: http://en.wikipedia.org /wiki/Cider

Classification of beverages. (2011). Retrieved from http:// en.inhotelmanagement.blogspot.com

Fruit wine. (2011). Retrieved from http://en.wikipedia.org/wiki/ fruit_wine

Heather, B. (2012). The process of wine making, Retrieved from http://www.whitman.edu/environmental_studies/WWRB/winema king.htm

Himachal heady with the success of fruit wines. (2006, September 29). Indian Express.

Hsu, C. H. C., Kang, S. K. \& Wolfe, K. (2002). Psychographic and demographic profiles of niche market leisure travelers. Journal of Hospitality \& Tourism Research, 26(1), 3-22.

Indian wine. (2011). Retrieved from http://en.wikipedia.org/wiki/ Indian_wine

Jandi. (2011, August 29). Restaurant benefit from summer tourism. Retrieved from http://www.kng.com/blog/food-and-beveragenews/restaurants-benefit-from-summer-tourism

Keown, C. \& Casey, M. (1995). Purchasing behaviour in the Northern Ireland wine market. British Food Journal, 97 (1), 17 - 20.

Lillicrap, D., Cousins, J., \& Smith, R. (1998). Food and Beverage Service (5th ed.). Tottenham, London: Hodder \& Stoughton.

O'Neill, M. and Charters, S. (2000). Service quality at the cellar door: Implications for

Oliver, R. L. (1993). Cognitive, affective and attribute bases of the satisfaction response. Journal of Consumer Research, 20, 418 - 430.

Oliver, R. L. (1997). Satisfaction: A behavioral perspective on the consumer. Boston: McGraw-Hill.

Tempest cider. (1999-2010). Retrieved from http://www.alibaba.com/ product-free/107025296/ TEMPEST_CIDER.html

The resource for people in Tourism. (2012). Retrieved from http:/ /www.go2hr.ca/ BCsTourismbrIndustry/ WhatisTourism/ tabid/ 71/ Default.aspx

Types of wines. (2009-2011). Retrieved from http://www.wineabout.com/ 
Vinexpo asia-pacific. (2010). Retrieved from http:/ / www.vinexpo.com

Western Australia's developing wine tourism industry. Managing service quality, 10(2), 112.

Yuksel, A. \& Pimmington, M. (1998). Customer Satisfaction Measurement. Cornell Hotel and Restaurant Administration Quarterly, 39(6), 60-70. 